\title{
Influence of Heavy Metals and Nutrient Concentrations on Selenium Geochemical Behavior in Soil-Rice System
}

\author{
Tianyuan Li, Xuyin Yuan*, Yinxian Song**, Hongyan Chen, Qing Liu, Sun Hu \\ Key Laboratory for Integrated Regulation and Resources Development on Shallow Lakes, \\ Ministry of Education, College of the Environment, Hohai University, \\ Nanjing 210098, Jiangsu, PR China
}

Received: 6 October 2015

Accepted: 3 December 2015

\begin{abstract}
Selenium deficiency in crops has become a subject of growing concern where soil Se concentration is low. The mechanisms of Se translocation in the soil-rice system is very complex and the influence of heavy metal elements and nutrient concentrations on Se translocation in the soil-rice system is unknown. Our study investigated concentrations of $\mathrm{Se}$, heavy metals like $\mathrm{Hg}, \mathrm{Cd}$, and $\mathrm{Pb}$, and nutrient elements like $\mathrm{Ca}, \mathrm{K}, \mathrm{P}$, and $\mathrm{S}$ in soils and rice tissues (roots, stems, and grains) in different industrial regions in Jiangsu Province, China. The transfer of Se in the soil-rice system was calculated by transfer coefficients $\left(\mathrm{TC}_{\mathrm{Se}}\right)$ in this study. The results showed that Se transfer from soil to roots and from stems to grain were key steps for controlled Se concentration in rice grains. The multiple linear regression analysis makes an implication that some elements influence the Se transfer significantly: soil $\mathrm{K}$ and $\mathrm{Hg}$ may suppress Se entering rice roots; $\mathrm{B}, \mathrm{Cu}$, and Mo in rice root may restrain Se transfer from root to stem; and $\mathrm{S}, \mathrm{Cr}, \mathrm{P}$, and $\mathrm{Mg}$ in rice stem had negative effects on Se accumulation in rice grain. Therefore, reducing heavy metal pollution and managing fertilizer amounts may elevate Se concentration in rice grain, especially when Se concentration in soils is low.
\end{abstract}

Keywords: transfer factors, selenium, soil, rice

\section{Introduction}

Selenium (Se) is one of the essential micronutrient elements for human health. Insufficient Se intake has been shown to increase the risk of developing cancer and heart disease, Keshan disease, and white muscle disease

*e-mail: yxy_hjy@hhu.edu.cn

**e-mail: songyinxian@gmail.com in mammals, and to cause hypothyroidism and immune system dysfunction in humans [1-4]. Meanwhile, although $\mathrm{Se}$ is not an essential element for plants, low doses of Se are believed to be beneficial for plants and can be used to alleviate abiotic stresses such as cold, drought, high light, water, salinity, and heavy metals [5-7]. Like other microelements, selenium content in soils is influenced by parent materials and human activities, and the distribution character of Se contents in soil is heterogeneous [8]. In many regions of the world, soil Se concentration is low $\left(<0.6 \mathrm{mg} \mathrm{kg}^{-1}\right)$, especially in some parts of China [9]. 
Meanwhile, in the southwest United States [10], Egypt [11], and Hubei Province in China [12], soils contains high concentrations of Se.

People mainly acquire Se from plant foods, especially cereals [13]. Because of the low content of Se in foods, the daily Se intake is insufficient to meet the requirement for human health in some parts of the world [14]. Some studies have been made to prevent Se deficiency in plant foods, such as using selenized fertilizers [15] or changing the irrigation management [16]. But these methods may increase the cost of agricultural products and bring potential risks to the environment [17]. In addition, using selenide fertilizers to improve Se content in plants was constrained by many factors. For example, Se exhibits a broad range of oxidation states in soils. Selenate is the most mobile Se form, and at low redox potential it can be reduced to selenite, which has a much higher adsorption affinity. Selenite can be strongly retained by ligand exchange on oxide surfaces, especially at low $\mathrm{pH}$, which reduces its bioavailability [18]. Thus a selenite addition to aerobic soil rather than flooded soil was an effective way to increase Se concentration in rice [16]. Stroud et al. [19] found that Se fertilization up to $20 \mathrm{~g} \mathrm{ha}^{-1}$ did not lead to significant Se accumulation in the soil, suggesting losses of Se unutilized by the crop. To this end, it is important to find another method to improve Se contents in rice more efficiently, especially in actual situations rather than the laboratory study.

Several studies have been carried out regarding the interaction between nutrient elements or heavy metals and $\mathrm{Se}$ in the soil-plant system [20-22], but most of them focused on the laboratory study, or just discuss the influence of a single element on the transfer of Se in the soil-plant system. In fact, Se concentration in plant tissues is affected by many factors, such as contents of soil $\mathrm{Mg}, \mathrm{K}$, $\mathrm{S}, \mathrm{Hg}, \mathrm{Cd}$, and Se speciation in soils [19, 23]. Moreover, few studies have discussed the transfer of Se from soil to edible parts of the plants step by step (soil-to-root, root-to-stem, and stem-to-grain), thus the key steps of the Se transfer process in soil-plant systems remains unknown.

Jiangsu Province is one of the most developed provinces in China. The industrial activities in southern Jiangsu Province have caused serious environmental problems, especially heavy metal pollution of soil $[24,25]$. Meanwhile, the content of some nutrient elements like P, $\mathrm{S}, \mathrm{K}, \mathrm{Ca}$, and $\mathrm{Mg}$ in the soil have been elevated due to excessive agricultural activities such as overfertilization. Soil $\mathrm{pH}$ also has decreased in the past decade, as has been reported by several recent studies $[8,26]$. The Se content and transfer in the soil-rice system in southern Jiangsu is unknown; the influencing factors and the key steps of Se transfer in the main production areas for food crops in China with elevated soil heavy metals and nutrient elements need to be studied. The objectives of this research include:

1) to investigate the content of heavy metal and nutrient elements in soil and rice in the study areas;

2) to study Se transfer in the soil-rice system step
Table 1. Heavy metal element concentrations in soil and rice tissues from four areas $\left(\mathrm{mg} \mathrm{kg}^{-1}, \mathrm{n}=56\right)$.

\begin{tabular}{|c|c|c|c|c|c|}
\hline Element & Region & Soil & Root & Stem & Grain \\
\hline \multirow{4}{*}{ As } & WT & 10.80 & 1.10 & 0.51 & 0.08 \\
\hline & YF & 16.49 & 1.73 & 4.66 & 0.18 \\
\hline & DS & 9.49 & 18.99 & 1.98 & 0.13 \\
\hline & LX & 8.33 & 1.81 & 2.31 & 0.13 \\
\hline \multirow{4}{*}{$\mathrm{Cd}$} & WT & 0.24 & 1.10 & 0.22 & 0.03 \\
\hline & YF & 4.64 & 7.84 & 2.07 & 0.27 \\
\hline & DS & 12.64 & 18.99 & 5.82 & 1.02 \\
\hline & LX & 0.24 & 1.81 & 0.38 & 0.07 \\
\hline \multirow{4}{*}{ Co } & WT & 13.64 & 1.39 & 0.15 & 0.01 \\
\hline & YF & 12.64 & 1.73 & 0.25 & 0.01 \\
\hline & DS & 12.70 & 2.95 & 0.26 & 0.01 \\
\hline & LX & 8.96 & 3.18 & 0.58 & 0.01 \\
\hline \multirow{4}{*}{$\mathrm{Cr}$} & WT & 77.75 & 19.58 & 4.58 & 0.56 \\
\hline & YF & 80.72 & 16.59 & 7.36 & 0.40 \\
\hline & DS & 69.94 & 28.75 & 5.44 & 0.37 \\
\hline & LX & 63.26 & 19.55 & 5.31 & 0.58 \\
\hline \multirow{4}{*}{$\mathrm{Cu}$} & WT & 38.16 & 42.97 & 6.89 & 4.30 \\
\hline & YF & 53.08 & 64.36 & 7.64 & 4.36 \\
\hline & DS & 26.64 & 32.24 & 4.11 & 3.92 \\
\hline & LX & 17.69 & 31.25 & 3.24 & 3.06 \\
\hline \multirow{4}{*}{$\mathrm{Hg}$} & WT & 0.59 & 0.05 & 0.03 & 0.01 \\
\hline & YF & 0.18 & 0.04 & 0.04 & 0.00 \\
\hline & DS & 0.19 & 0.05 & 0.03 & 0.00 \\
\hline & LX & 0.07 & 0.04 & 0.03 & 0.01 \\
\hline \multirow{4}{*}{ Mo } & WT & 0.82 & 0.64 & 0.20 & 0.52 \\
\hline & YF & 0.80 & 0.38 & 0.51 & 0.41 \\
\hline & DS & 0.85 & 0.68 & 0.51 & 0.51 \\
\hline & LX & 0.91 & 0.71 & 0.34 & 0.54 \\
\hline \multirow{4}{*}{$\mathrm{Ni}$} & WT & 31.81 & 3.09 & 0.54 & 0.78 \\
\hline & YF & 37.64 & 4.06 & 0.77 & 0.74 \\
\hline & DS & 25.63 & 4.81 & 0.52 & 0.65 \\
\hline & LX & 16.94 & 2.92 & 0.52 & 1.04 \\
\hline \multirow{4}{*}{$\mathrm{Pb}$} & WT & 47.73 & 6.23 & 0.73 & 0.08 \\
\hline & YF & 78.91 & 10.27 & 1.64 & 0.08 \\
\hline & DS & 44.31 & 11.49 & 1.46 & 0.10 \\
\hline & LX & 28.34 & 9.03 & 1.49 & 0.10 \\
\hline \multirow{4}{*}{$\mathrm{Zn}$} & WT & 95.24 & 85.05 & 35.52 & 20.96 \\
\hline & YF & 133.62 & 157.05 & 69.24 & 18.14 \\
\hline & DS & 76.97 & 108.82 & 61.07 & 20.46 \\
\hline & LX & 45.39 & 102.88 & 48.44 & 17.92 \\
\hline
\end{tabular}


by step and to find out the key steps controlling Se concentration in rice grains;

3) to select the critical factors from numerous parameters that influence Se transfer in the soil-rice system.

\section{Materials and Methods}

\section{Study Areas and Samplings}

Southern Jiangsu Province consists of Changzhou, Wuxi, and Suzhou. Yifeng (YF), Dingshu (DS), and Wangting (WT) were chosen as representative of the three large cities mentioned above, respectively. Langxi (LX) was selected as a contrast area in this study, for it is not significantly influenced by human activity. Varieties of industries, including chemical and foundry, are located in YF. Dingshu is famous for its ceramics. WT was responsible for electric power supply for Suzhou, and two large thermal power plants are located in this region. Rice is the stable food in southern Jiangsu Province, where the most common rice type is Indica.

At harvest time a total of 56 samples were collected from YF, DS, WT, and LX (14 samples for each area) randomly. The rice and their corresponding soil samples (0-15 cm in depth) were collected from each site. Each sample was mixed with at least five sub-samples at the sampling site. Species of all of the rice samples collected were Indica rice. Rice samples were separated into grains, stems, and roots.

\section{Chemical Analysis}

Soil samples were air-dried at room temperature, then ground to pass through a 100 -mesh sieve for elements analysis. Rice samples (grain, stem, and root) were ovendried at $105^{\circ} \mathrm{C}$ for $1 \mathrm{~h}$, then $70^{\circ} \mathrm{C}$ to constant weight, then ground to pass through a 100 -mesh sieve for further analysis.

For analysis of the total concentrations of heavy metals, soil samples were digested by a $\mathrm{HClO}_{4}-\mathrm{HNO}_{3}-$ HF mixture in teflon tubes. Rice samples were digested by $\mathrm{HClO}_{4}-\mathrm{HNO}_{3}(4: 1)$. The concentrations of $\mathrm{Se}, \mathrm{Cr}, \mathrm{Cu}$, $\mathrm{Pb}, \mathrm{Cd}, \mathrm{Co}, \mathrm{Mo}, \mathrm{Ni}, \mathrm{Pb}, \mathrm{Zn}, \mathrm{B}, \mathrm{Ca}, \mathrm{Fe}, \mathrm{K}, \mathrm{Mg}, \mathrm{Mn}, \mathrm{P}$, and $\mathrm{S}$ were determined by inductively coupled plasma mass spectroscopy (XSERIES, Thermo Electron, USA). Arsenic and $\mathrm{Hg}$ were detected by a cold atomic fluorescent spectrophotometer (AFS-230E, China). Quality assurance and quality control (QA/QC) for metals in soil samples were estimated by determining the metal contents of the blank and duplicate samples and certified reference materials. Certified reference material GBW10010 (GSB-1) was used to validate elemental concentrations in rice plants, while GBW07442, 07443 (GSF-2, 3), GBW07402, 07403, 07404, and 07406 (GSS-2, 3, 4, 6) were used for validating elemental concentrations in soils. The recovery of GSB-1 was $93-105 \%$ and the recovery of GSF-2, 3 and GSS-2, 3, 4, 6 was $95-105 \%$ for all of the elements. The relative difference (RD) in values for all
Table 2. Total concentrations of nutrient elements in soil and rice tissues from four areas $\left(\mathrm{mg} \mathrm{kg}^{-1}, \mathrm{n}=56\right)$.

\begin{tabular}{|c|c|c|c|c|c|}
\hline Element & Region & Soil & Root & Stem & Grain \\
\hline \multirow{4}{*}{ B } & WT & 80.14 & 5.60 & 2.35 & 0.77 \\
\hline & YF & 63.11 & 6.15 & 3.04 & 0.86 \\
\hline & DS & 76.67 & 9.13 & 3.31 & 1.13 \\
\hline & LX & 79.47 & 7.17 & 3.02 & 0.81 \\
\hline \multirow{4}{*}{$\mathrm{Ca}$} & WT & 8461.86 & 2064.62 & 982.86 & 88.70 \\
\hline & YF & 6841.84 & 2202.50 & 1297.57 & 113.86 \\
\hline & DS & 5781.08 & 2254.85 & 1389.93 & 94.96 \\
\hline & LX & 3132.14 & 2079.50 & 1543.54 & 127.51 \\
\hline \multirow{4}{*}{$\mathrm{Fe}$} & WT & 35288.48 & 4111.54 & 159.50 & 14.22 \\
\hline & YF & 36140.00 & 6062.21 & 326.71 & 12.18 \\
\hline & DS & 30791.23 & 9943.69 & 211.14 & 9.75 \\
\hline & LX & 21638.17 & 10592.58 & 238.62 & 13.39 \\
\hline \multirow{4}{*}{ K } & WT & 15434.61 & 5447.38 & 16047.43 & 1625.57 \\
\hline & YF & 15380.70 & 2629.50 & 27011.29 & 2326.29 \\
\hline & DS & 12880.46 & 3094.69 & 25822.00 & 1682.14 \\
\hline & LX & 10653.96 & 5432.50 & 23749.38 & 1823.92 \\
\hline \multirow{4}{*}{$\mathrm{Mg}$} & WT & 6343.75 & 1228.00 & 1181.14 & 764.14 \\
\hline & YF & 5644.29 & 1094.79 & 1647.36 & 825.71 \\
\hline & DS & 3315.99 & 1169.69 & 1728.00 & 663.71 \\
\hline & LX & 2738.72 & 1470.92 & 1473.23 & 693.15 \\
\hline \multirow{4}{*}{$\mathrm{Mn}$} & WT & 569.42 & 302.92 & 523.50 & 18.14 \\
\hline & YF & 455.07 & 292.07 & 576.93 & 25.65 \\
\hline & DS & 428.00 & 296.54 & 549.29 & 22.98 \\
\hline & LX & 273.09 & 301.50 & 770.08 & 25.21 \\
\hline \multirow{4}{*}{$\mathrm{P}$} & WT & 748.00 & 1029.62 & 751.00 & 2122.43 \\
\hline & YF & 897.90 & 1573.86 & 1596.71 & 2347.86 \\
\hline & DS & 699.08 & 1444.15 & 1461.29 & 1963.07 \\
\hline & LX & 626.45 & 2008.67 & 1320.38 & 2310.08 \\
\hline \multirow{4}{*}{$\mathrm{S}$} & WT & 566.50 & 2130.08 & 1392.71 & 1104.21 \\
\hline & YF & 604.86 & 2520.29 & 1948.64 & 1254.00 \\
\hline & DS & 613.42 & 2498.38 & 1904.36 & 1264.50 \\
\hline & LX & 442.73 & 2746.67 & 1724.08 & 1134.77 \\
\hline \multirow{4}{*}{$\mathrm{Se}$} & WT & 0.48 & 0.18 & 0.07 & 0.06 \\
\hline & YF & 0.79 & 0.34 & 0.15 & 0.10 \\
\hline & DS & 1.78 & 1.29 & 0.41 & 0.28 \\
\hline & LX & 0.53 & 0.44 & 0.14 & 0.11 \\
\hline
\end{tabular}

replicates was lower than 5\%. All element concentrations in this work are expressed in the form of quantity contained in per kilogram dry weight sample (unit: $\mathrm{mg} / \mathrm{kg}$ d.w.). 


\section{Statistical Analysis}

Descriptive statistics were used to calculate the mean, maximum, minimum, and standard deviation (SD) of element contents in soils and rice plants. Multivariate statistics, including multivariate regression analysis and correlation analysis, were performed using SPSS 19.0 (SPSS Inc., Chicago, USA). The figures were produced using Origin 7.0 (OriginLab Inc., Hampton, USA).

\section{Results and Discussion}

\section{Concentrations of Se and Other Elements in Soils}

The mean concentration of $\mathrm{Se}$ in soils in the study areas is shown in Table 2. The mean concentrations of soil Se in WT, YF, DS, and LX were 0.48 (0.23-0.59), 0.79 (0.49-1.52), 1.78 (1.01-2.69), and 0.53 (0.37-0.66) $\mathrm{mg} \mathrm{kg}^{-}$ ${ }^{1}$. In WT, YF, and LX, Se concentrations were 0 to $1 \mathrm{mg}$ $\mathrm{kg}^{-1}$, which was comparable to Se concentration in Japan [27]. Elevated Se concentration was only observed in the DS area. In this study, Se concentration less than $1.0 \mathrm{mg}$ $\mathrm{kg}^{-1}$ was considered low Se soil; if not, soil was considered high Se soil. Using this criteria, soils collected from WT, YF, and LX were low Se soil, whereas soils in DS were high Se soil.

Due to human activity, heavy metals and some nutrient elements in soil have been elevated with different degrees in YF, DS, and WT. Tables 1 and 2 present the contents of heavy metals and nutrient elements in soils, respectively. High contents of $\mathrm{Hg}, \mathrm{Co}$, and $\mathrm{Cu}$ in soil samples may be caused by the power plant in WT, while the elevated contents of $\mathrm{B}, \mathrm{Ca}, \mathrm{K}, \mathrm{Mg}$, and $\mathrm{Mn}$ in soils may be due to flourishing agricultural activities like overfertilization [28]. The variety of industries in YF may bring considerable $\mathrm{As}, \mathrm{Cr}, \mathrm{Cu}, \mathrm{Ni}, \mathrm{Pb}$, and $\mathrm{Zn}$ into the soil. According to Liao et al. [29], soils collected from DS had the highest $\mathrm{Cd}$ content, which can be explained by the widespread ceramic industries in this region. Meanwhile,

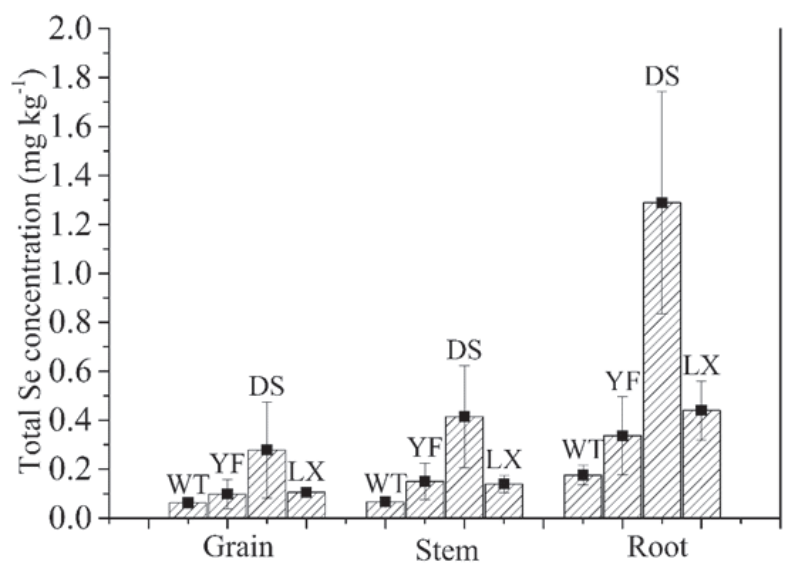

Fig 1. Total Se concentrations in different tissues of rice plants collected from four areas (with Std. Error). the contents of the other heavy metal elements were relatively low in the DS region compared to those from WT and YF. Generally, soils collected from LX had the lowest contents of the investigated elements.

\section{Se in Rice Tissues}

Se concentrations varied between the tissues of rice plants collected from the four areas (Fig. 1). For rice plants collected from the four areas, the highest concentration of Se was found in roots, and the average concentrations were $0.18\left(0.10-0.26 \mathrm{mg} \mathrm{kg}^{-1}\right), 0.34(0.19$ $\left.0.70 \mathrm{mg} \mathrm{kg}^{-1}\right), 1.29\left(0.61-2.02 \mathrm{mg} \mathrm{kg}^{-1}\right)$, and $0.44(0.29$ $0.68 \mathrm{mg} \mathrm{kg}^{-1}$ ) for WT, YF, DS, and LX, respectively. These results were in accordance with other studies in which $\mathrm{Se}$ mainly accumulate in rice roots [30, 31]. Huang et al. [32] reported that the iron plaque on root surfaces had a high affinity for selenite and might act as a pool to Se uptake. For rice grains, average Se concentrations of DS and LX were 0.280 and $0.105 \mathrm{mg} \mathrm{kg}^{-1}$, respectively. Foods that contain less than $0.1 \mathrm{mg} \mathrm{kg}^{-1}$ Se may lead to Se-deficiency [33]. Using this criterion value, rice grains in the DS and LX areas were abundant in SE, whereas rice collected from the WT and YF areas lacked Se (average concentrations 0.063 and $0.099 \mathrm{mg} \mathrm{kg}^{-1}$, respectively). Fig. 1 shows that the concentration of $\mathrm{Se}$ in rice tissues collected from all of the study areas follows the trend root $>$ stem $>$ grain, an observation that is in agreement with the findings of Zhang et al. [34], who investigated the distribution of Se in rice in Wanshan in Guizhou provinces.

\section{Transfer Coefficients of Se in the Soil-Rice System}

The partition of Se content in the soil-rice system is shown in Fig. 2. In respect to Se concentration per unit mass, more than half of Se in WT and YF areas $(60.59 \%$
A

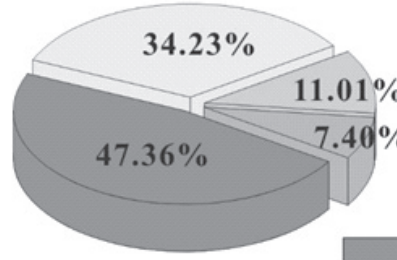

C

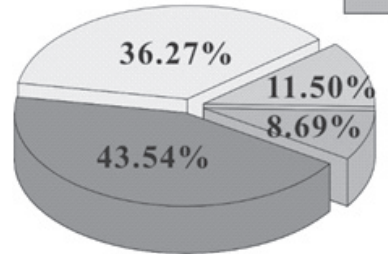

B

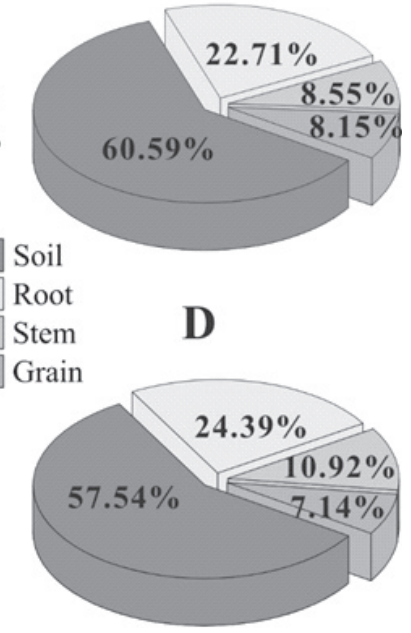

Fig 2. Relative distribution of $\mathrm{Se}$ in the soil-rice system from four areas (A-DS, B-WT, C-LX, D-YF). 
and $57.54 \%$, respectively) stayed in soils, while $52.64 \%$ and $56.46 \%$ of Se occurred in rice plants in the DS and LX areas. Compared to WT and YF, Se concentration in rice roots collected from DS and LX was about 10\% higher. Most Se was stored in roots after entering rice plants. According to Zhu [35], selenite is mostly assimilated in the roots, and rapidly converted to organic forms of Se and retained in the roots. Distribution of $\mathrm{Se}$ in rice stems and grains in four areas follows the trend $\mathrm{LX}>\mathrm{DS}>\mathrm{YF}>\mathrm{WT}$ and $\mathrm{LX}>\mathrm{WT}>\mathrm{DS}>\mathrm{YF}$, respectively. Distribution of Se in the soil-rice system had some differences throughout the four study areas, despite rice plants being within the same variety, which indicates that the other elements' content distribution pattern in the soil-rice system may influence Se distribution in rice plants.

To investigate the transfer and accumulation of $\mathrm{Se}$ in rice tissues, transfer coefficients $\left(\mathrm{TC}_{\mathrm{Se}}\right)$ were calculated. In this study, Se transfer from soil to rice was separated into 3 steps. The $\mathrm{TC}_{\mathrm{Se}}$ was defined as follows, according to Green and Tibbett [36]:

$$
\begin{aligned}
\mathrm{TC}_{\text {Se soil/root }} & =\mathrm{C}_{\text {root }} / \mathrm{C}_{\text {soil }} \\
\mathrm{TC}_{\text {Se root/stem }} & =\mathrm{C}_{\text {stem }} / \mathrm{C}_{\text {root }} \\
\mathrm{TC}_{\text {Se stem/grain }} & =\mathrm{C}_{\text {grain }} / \mathrm{C}_{\text {stem }}
\end{aligned}
$$

...where $\mathrm{C}$ is the measured concentration of Se in the soil (or root, or stem, or grain).

The $\mathrm{TC}_{\mathrm{Se}}$ of the rice plants are presented in Fig. 3. The $\mathrm{TC}_{\text {Se root/stem }}$ throughout the four areas was similar. However, there was a significant difference for $\mathrm{TC}_{\mathrm{Se} \text { soil /root }}$ and $\mathrm{TC}_{\mathrm{Se} \mathrm{stem/grain}}$. For $\mathrm{TC}_{\mathrm{Se} \text { root/soil }}$, rice collected from $\mathrm{LX}$ has the highest value reached 0.85 , while WT was only 0.38 . The same distinct phenomenon appeared for $\mathrm{TC}_{\mathrm{S}}$ with the four areas following the trend $\mathrm{WT}>\mathrm{LX}>\mathrm{DS}=\mathrm{YF}$. This indicated that Se transfers from soil to root and stem to grain were the key factors controlling Se concentration in rice grains. This conclusion is opposite Se transfer in brown rice. Zhang et al. [37] found that Se transported

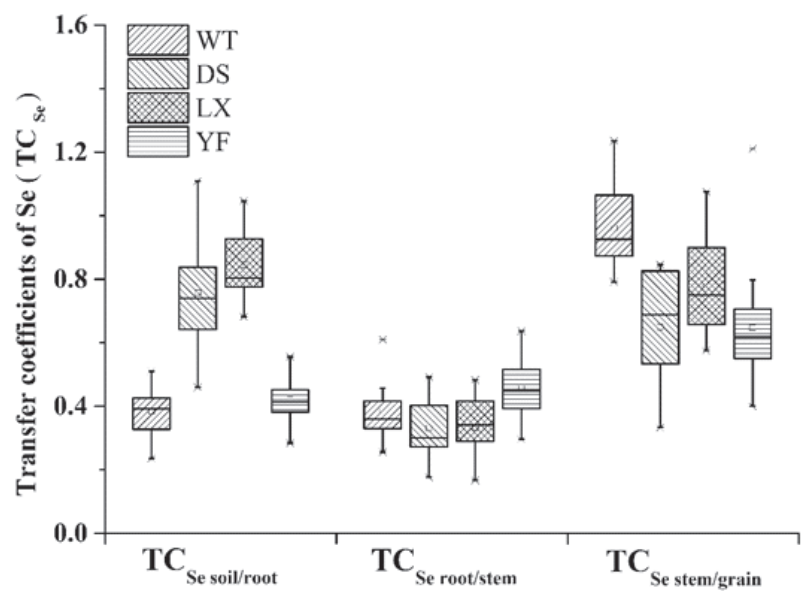

Fig 3. Transfer coefficients (TC Se) in different rice plant tissues in study areas.
Table 3. Transfer coefficients $\left(\mathrm{TC}_{\mathrm{Se}}\right)$ in different tissues of the rice plant in the study areas.

\begin{tabular}{|c|c|c|c|c|}
\hline Area & $\mathrm{TC}_{\text {Se }}$ & Mean & Std & $\mathrm{CV}$ \\
\hline \multirow{4}{*}{ WT } & $\mathrm{TC}_{\text {Se soil/root }}$ & 0.38 & 0.08 & 0.20 \\
\cline { 2 - 5 } & $\mathrm{TC}_{\text {Se rootstem }}$ & 0.38 & 0.09 & 0.23 \\
\cline { 2 - 5 } & $\mathrm{TC}_{\text {Se stem/grain }}$ & 0.96 & 0.13 & 0.13 \\
\hline \multirow{4}{*}{$\mathrm{DS}$} & $\mathrm{TC}_{\text {Se soil /root }}$ & 0.76 & 0.19 & 0.25 \\
\cline { 2 - 5 } & $\mathrm{TC}_{\text {Se root/stem }}$ & 0.33 & 0.09 & 0.28 \\
\cline { 2 - 5 } & $\mathrm{TC}_{\text {Se stem/grain }}$ & 0.65 & 0.18 & 0.27 \\
\hline \multirow{3}{*}{$\mathrm{LX}$} & $\mathrm{TC}_{\text {Se soil/root }}$ & 0.85 & 0.12 & 0.14 \\
\cline { 2 - 5 } & $\mathrm{TC}_{\text {Se root/stem }}$ & 0.33 & 0.10 & 0.30 \\
\cline { 2 - 5 } & $\mathrm{TC}_{\text {Se stem/grain }}$ & 0.78 & 0.15 & 0.20 \\
\hline \multirow{4}{*}{$\mathrm{YF}$} & $\mathrm{TC}_{\text {Se soil/root }}$ & 0.42 & 0.08 & 0.18 \\
\cline { 2 - 5 } & $\mathrm{TC}_{\text {Se root/stem }}$ & 0.46 & 0.09 & 0.20 \\
\cline { 2 - 5 } & $\mathrm{TC}_{\text {Se stem/grain }}$ & 0.65 & 0.19 & 0.30 \\
\hline
\end{tabular}

from roots to stems was the key step in Se accumulation in rice seeds.

\section{Factors Influencing Se Transfer from Soil to Seeds in Rice}

The correlation between elements in the soil-rice system and $\mathrm{TC}_{\mathrm{Se}}$ in different parts is presented in Table 4. Nutrient elements like $\mathrm{K}, \mathrm{Mg}, \mathrm{P}$, and $\mathrm{S}$ and heavy metal elements like $\mathrm{As}, \mathrm{Cr}, \mathrm{Cu}, \mathrm{Ni}, \mathrm{Zn}$, and $\mathrm{Pb}$ in the soil were significantly negatively correlated with $\mathrm{TC}_{\mathrm{Se} \text { soil /root }}$ $(p<0.01, n=56)$, indicating that these elements in the soil may restrain Se uptake by rice roots. Previous studies demonstrated that Se often shows antagonistic effects on some essential elements such as phosphorus (P) [38, 39] and sulfur (S) [40]. In addition, elements like As and Se shared the same transporter with Si named OsNIP2; 1 [41]. In rice roots, elements like $\mathrm{B}, \mathrm{Fe}, \mathrm{Co}, \mathrm{Cr}, \mathrm{Mo}$, $\mathrm{Ni}$, and $\mathrm{Pb}$ were negatively correlated with $\mathrm{TC}_{\mathrm{Se} \text { root/stem, }}$, indicating that these elements may have adverse effects on Se transportation from roots to stems. For Se transfer from rice stem to grain, all of the investigated elements had negative effects. In recent years, the interaction of Se and other elements (including nutrient elements like $\mathrm{K}, \mathrm{Ca}$, $\mathrm{Mg}$, $\mathrm{P}$, and $\mathrm{Sm}$ and heavy metals like $\mathrm{Cd}, \mathrm{Hg}$, and $\mathrm{Cu}$ ) in the soil-plant system have been carried out. For example, $\mathrm{Se}-\mathrm{Hg}$ antagonism may exist in the soil-rice system in this study, but there have been few studies investigating this putative $\mathrm{Se}-\mathrm{Hg}$ antagonism in rice $[42,43]$. From these limited reports, the $\mathrm{Se}-\mathrm{Hg}$ antagonism in rice may be primarily due to the formation of a high molecular weight $\mathrm{Hg}$-Se-containing complex in plant roots. The complex is difficult to metabolize or translocate to aerial parts of plants [44]. An antagonism effect was also observed between $\mathrm{Cd}, \mathrm{Pb}$, and $\mathrm{Se}$ in a pot experiment, where Se application significantly decreased $\mathrm{Cd}$ and $\mathrm{Pb}$ concentrations in rice 


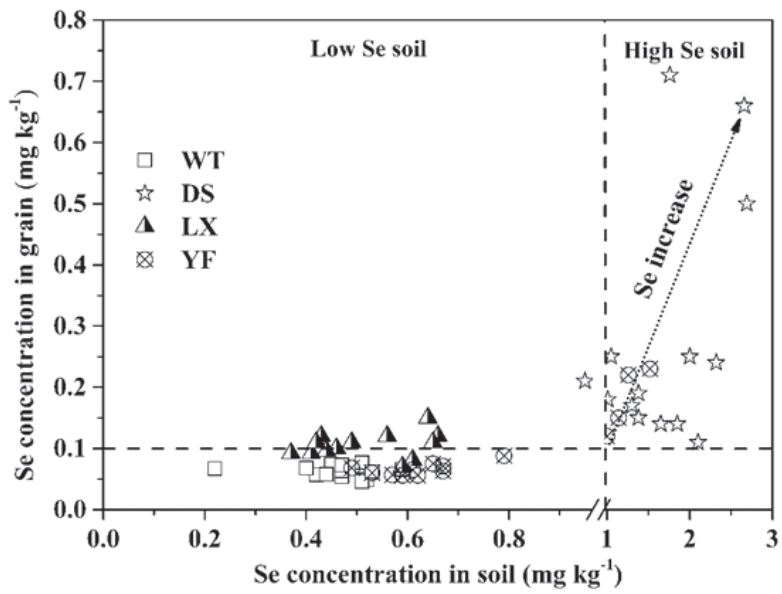

Fig 4. Se concentration change in rice grain with different soil $\mathrm{Se}$ (soil $\mathrm{Se}<1 \mathrm{mg} \mathrm{kg}^{-1}$, grain Se has no change with soil $\mathrm{Se}$; soil $\mathrm{Se}>1 \mathrm{mg} \mathrm{kg}^{-1}$, grain Se increases with soil Se.)

tissues [45]. Feng et al. [7] discovered that the contents of nutrient elements such as $\mathrm{Ca}, \mathrm{Mg}, \mathrm{K}, \mathrm{Fe}, \mathrm{Mn}$, and $\mathrm{Cu}$ were all restrained by $\mathrm{Se}$ in spite of its beneficial role for plant growth, which is in accordance with this study. Several studies have confirmed that $\mathrm{P}$ transporters are involved in Se uptake of some plants like Astragalus and Neptunia $[46,47]$. Some similar results were also found for the other nutrient elements: Selenium as S analog is taken up by plants via sulfate transporters in the roots [48]. In this study, what interested us is that soil total Se concentration has nearly no effect on promoting Se transfer in the entire soil-rice system, according to the correlation analysis. A large variety of studies demonstrated that total Se content in soil is not related to Se concentration in rice grain. Alifar and Rahman [49] stated that different selenium rates applied in soils did not affect the grain selenium level and grain yield of MR 219 rice. Fig. 4 showed that in low Se soils $\left(\mathrm{Se}<1 \mathrm{mg} \mathrm{kg}^{-1}\right)$, Se concentration in rice grains has no change with soil Se concentrations. For example, Se concentration in soils collected from WT, LX, and YF were below $1 \mathrm{mg} \mathrm{kg}^{-1}$, but rice grains collected from LX had higher Se concentrations than WT and YF. When soil contains more $\mathrm{Se}\left(>1 \mathrm{mg} \mathrm{kg}^{-1}\right)$, grain Se increases with soil Se concentration.

Based on the correlation analysis above, the best-fit models using multiple linear regression analysis (MLR) for predicting Se transfer coefficient from soil to root $\left(\mathrm{TC}_{\text {Se soil /root }}\right)$, root to stem $\left(\mathrm{TC}_{\text {Se root/stem }}\right)$, and stem to grain

Table 4. Correlation analysis between elements in soil, root, stem, and transfer coefficients $\left(\mathrm{TC}_{\mathrm{se}}\right)$ for different parts in the soil-rice system from four areas $(n=56)$.

\begin{tabular}{|c|c|c|c|c|c|}
\hline Concentration in soil & $\mathrm{TC}_{\text {Se rootsoil }}$ & Concentration in root & $\mathrm{TC}_{\text {Se root/stem }}$ & Concentration in stem & $\mathrm{TC}_{\text {Se stem/grain }}$ \\
\hline B & $.269^{*}$ & B & $-.542 * *$ & B & $-.597 * *$ \\
\hline $\mathrm{Ca}$ & $-.294^{*}$ & $\mathrm{Ca}$ & $-.283^{*}$ & $\mathrm{Ca}$ & $-.340^{* *}$ \\
\hline $\mathrm{Fe}$ & -.184 & $\mathrm{Fe}$ & $-.523^{* *}$ & $\mathrm{Fe}$ & $-.559 * *$ \\
\hline K & $-.478^{* *}$ & K & .121 & K & $-.650 * *$ \\
\hline $\mathrm{Mg}$ & $-.445^{* *}$ & $\mathrm{Mg}$ & -.126 & $\mathrm{Mg}$ & $-.663^{* *}$ \\
\hline Mn & -.176 & $\mathrm{Mn}$ & -.184 & $\mathrm{Mn}$ & $-.305^{*}$ \\
\hline $\mathrm{P}$ & $-.321 * *$ & $\mathrm{P}$ & -.167 & $\mathrm{P}$ & $-.618 * *$ \\
\hline $\mathrm{S}$ & $-.261 *$ & S & $-.247 *$ & $\mathrm{~S}$ & $-.628 * *$ \\
\hline As & $-.347 * *$ & As & -.106 & As & $-.529 * *$ \\
\hline $\mathrm{Cd}$ & .065 & $\mathrm{Cd}$ & .038 & $\mathrm{Cd}$ & -.136 \\
\hline $\mathrm{Co}$ & -.132 & Co & $-.515^{* *}$ & $\mathrm{Co}$ & $-.342 * *$ \\
\hline $\mathrm{Cr}$ & $-.538 * *$ & $\mathrm{Cr}$ & $-.349 * *$ & $\mathrm{Cr}$ & $-.241 *$ \\
\hline $\mathrm{Cu}$ & $-.440 * *$ & $\mathrm{Cu}$ & .222 & $\mathrm{Cu}$ & -.126 \\
\hline $\mathrm{Hg}$ & -.002 & $\mathrm{Hg}$ & $-.266^{*}$ & $\mathrm{Hg}$ & $-.410 * *$ \\
\hline Mo & .040 & Mo & $-.396^{* *}$ & Mo & $-.639 * *$ \\
\hline $\mathrm{Ni}$ & $-.437 * *$ & $\mathrm{Ni}$ & $-.380 * *$ & $\mathrm{Ni}$ & $-.369 * *$ \\
\hline $\mathrm{Zn}$ & $-.528 * *$ & $\mathrm{Zn}$ & .176 & $\mathrm{Zn}$ & $-.564 * *$ \\
\hline $\mathrm{Pb}$ & $-.414 * *$ & $\mathrm{~Pb}$ & $-.433 * *$ & $\mathrm{~Pb}$ & $-.406^{* *}$ \\
\hline $\mathrm{Se}$ & .064 & $\mathrm{Se}$ & -.238 & $\mathrm{Se}$ & -.206 \\
\hline
\end{tabular}

* Significant at $\mathrm{p}<0.05$ level $\quad * *$ Significant at $\mathrm{p}<0.01$ 
a)

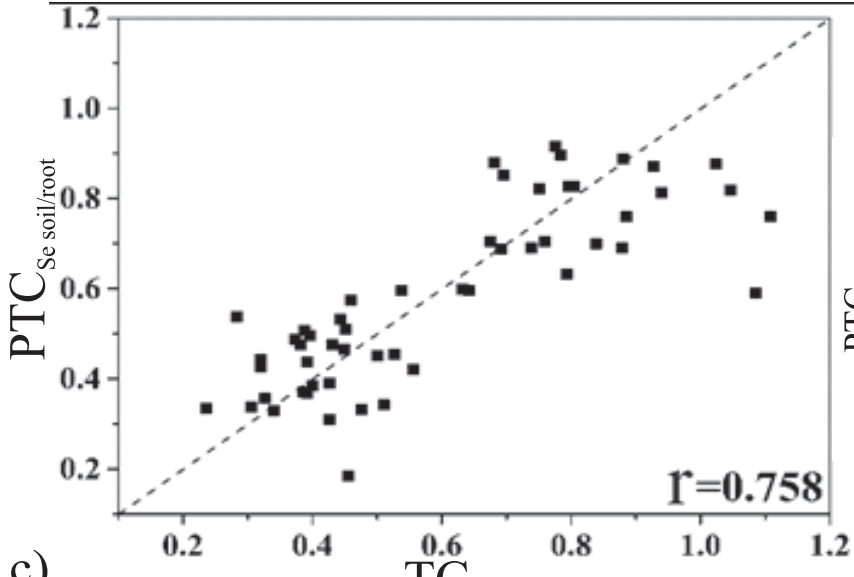

c)

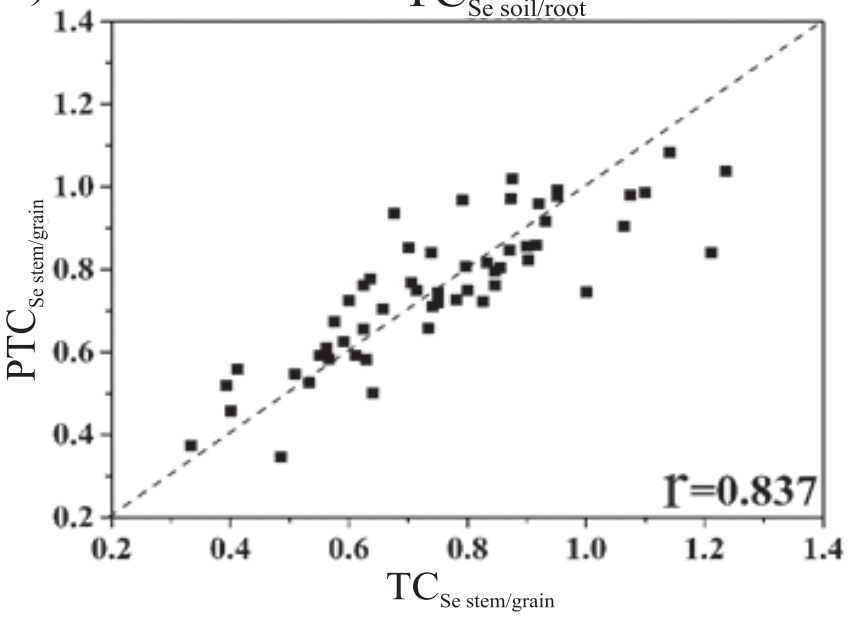

b)

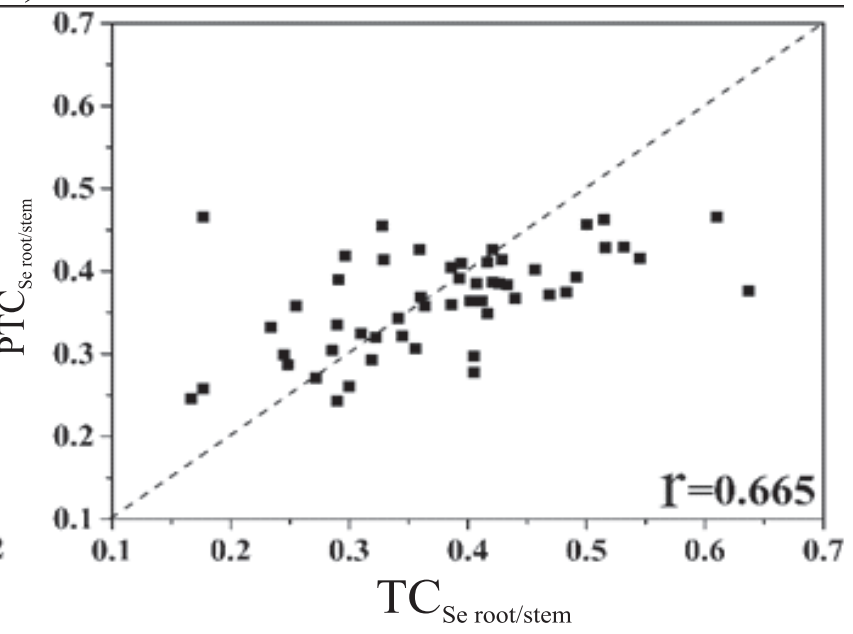

Fig 5. The predicted Se transfer coefficient (PTC Se) fit well with TC Se in this study, a) Se soil/root, b) Se root/stem, c) Se stem/grain.

$\left(\mathrm{TC}_{\text {Se stem/grain }}\right)$ were developed based on all of the nutrient and heavy metal elements in the soil-rice system.

According to multiple linear regression analysis using the stepwise method, $\mathrm{K}$ and $\mathrm{Hg}$ concentrations in the soil seem to be the most important elements restraining Se transfer from soil to root, the equations for $\mathrm{K}$ and $\mathrm{Hg}$ in the soil predicting $\mathrm{TC}_{\text {Se soil-root }}$ was as follows:

$$
\begin{gathered}
\mathrm{TC}_{\text {Se root/soil }}=1.621-7.021 * 10^{-5} \text { Soil }_{\mathrm{K}} \\
-0.351 \text { Soil }_{\mathrm{Hg}}(\mathrm{r}=0.758)
\end{gathered}
$$

With the same method, elements that may control Se transfer from root to stem and from stem to grain were also found by MLR; some elements were excluded by stepwise procedure, and the equations were as follows:

$$
\begin{gathered}
\mathrm{TC}_{\text {Se rootstem }}=0.466-0.012 \text { Root } \mathrm{B}+0.001 \text { Root } \mathrm{Cu} \\
-0.104 \text { Root Mo }(\mathrm{r}=0.665) \\
\mathrm{TC}_{\text {Se stem/grain }}=1.569-1.636^{*} 10^{-4} \text { Stem } \mathrm{S}-0.025 \\
\text { Stem Cr }-9.445^{*} 10^{-5} \text { Stem } \mathrm{P}-1.759^{*} 10^{-4} \text { Stem } \mathrm{Mg} \\
(\mathrm{r}=0.837)
\end{gathered}
$$

After $\mathrm{TC}_{\mathrm{Se}}$ was predicted and the predicted value $\left(\mathrm{PTC}_{\mathrm{Se}}\right)$ and $\mathrm{TC}_{\mathrm{Se}}$ were plotted (Fig. 5). The prediction model can predict accurately Se transfer in each step. Although the rice plants were collected from paddy fields in different areas, the $r$ value for the best-fit models ranged from 0.665 to 0.837 , indicating that these models were very effective in explaining factors influencing Se transfer in the soil-rice system, especially in the actual situations. Besides, according to correlation analysis, except for Se in soil, roots, and stems, the other nutrient and heavy metal elements may also play some role in influencing Se transfer in the soil-rice system.

\section{Conclusions}

Selenium concentration in soil and rice plants is different throughout the four areas. In WT, LX, and YF, Se concentration in soil is less than $1.0 \mathrm{mg} \mathrm{kg}^{-1}$, otherwise relatively high Se occurred in DS soil. Se concentration in rice grain is also different in study areas. Rice grain collected from DS and LX is rich in Se, although low Se concentration is in LX soil and high Se in DS soil. 
According to correlation analysis, nutrient elements like $\mathrm{Ca}, \mathrm{Fe}, \mathrm{K}, \mathrm{Mg}, \mathrm{P}$, and $\mathrm{S}$ and heavy metal elements (Co, $\mathrm{As}, \mathrm{Cr}, \mathrm{Ni}, \mathrm{Zn}, \mathrm{Pb}$, and $\mathrm{Hg}$ ) in soil and rice plants have negative correlation with $\mathrm{Se}$ in rice grains. These indicate that not only Se but also some heavy metals and other nutrient elements in soil could affect the Se transfer from soil to rice grains.

The differences of transfer coefficients of Se in the soilrice plant system in our study area demonstrate that the key stages of Se transfer are soil to root and stem to grain. Multiple linear regression analysis make an implication that some elements influence Se transfer significantly: soil $\mathrm{K}$ and $\mathrm{Hg}$ may suppress Se entering into rice roots; $\mathrm{B}, \mathrm{Cu}$, and $\mathrm{Mo}$ in rice roots may restrain Se transfer from root to stem; $\mathrm{S}, \mathrm{Cr}, \mathrm{P}$, and $\mathrm{Mg}$ in rice stem had negative effects on Se accumulation in rice grains. We therefore propose that remediation of heavy metal-polluted soil and management of fertilizing with nutrient elements could help enrich Se in rice grains, especially in areas with low soil Se.

\section{Acknowledgements}

This research was sponsored by the National Natural Science Foundation of China (41372354) and a project of the China Geological Survey (12120114092001) and the Priority Academic Program Development of Jiangsu Higher Education Institutions. The authors would like to thank Xueqiang Zhao and Hailong Chen for the sampling and laboratory work.

\section{References}

1. COMBS G. F. Food system-based approaches to improving micronutrient nutrition: The case for selenium. Biofactors. 12 (1), 39, 2000

2. FORDYCE F. M., GUANGDI Z., GREEN K., XINPING L. Soil, grain and water chemistry in relation to human selenium-responsive diseases in Enshi District, China. Applied Geochemistry. 15 (1), 117, 2000.

3. WANG Z., GAO Y. Biogeochemical cycling of selenium in Chinese environments. Applied Geochemistry. 16 (11), 1345, 2001

4. KŁAPCIŃSKA B., POPRZĘCKI S., DANCH A. Blood selenium concentration of residents of Upper Silesia: relation to age and gender. Pol J Environ Stud. 15, 753, 2006.

5. FENG R., WEI C., TU S. The roles of selenium in protecting plants against abiotic stresses. Environmental and Experimental Botany. 87 (0), 58, 2013.

6. FENG R., WEI C., TU S., DING Y., SONG Z. A Dual Role of Se on Cd Toxicity: Evidences from the Uptake of $\mathrm{Cd}$ and Some Essential Elements and the Growth Responses in Paddy Rice. Biological Trace Element Research. 151 (1), 113, 2013.

7. FENG R., WEI C., TU S., LIU Z. Interactive effects of selenium and antimony on the uptake of selenium, antimony and essential elements in paddy-rice. Plant and Soil. 365 (1), 375, 2013.

8. LIAO Q.L., EVANS L.J., GU X., FAN D.F., JIN Y., WANG H. A regional geochemical survey of soils in Jiangsu Province, China: preliminary assessment of soil fertility and soil contamination. Geoderma. 142 (1), 18, 2007.

9. FANG W.X., WU P. W., HU R.H., HUANG Z.Y. Environmental Se-Mo-B deficiency and its possible effects on crops and Keshan-Beck disease (KBD) in the Chousang area, Yao county, Shaanxi Province, China. Environmental Geochemistry and Health. 25 (2), 267, 2003.

10. ELLIS D. R., SALT D. E. Plants, selenium and human health. Current Opinion in Plant Biology. 6 (3), 273, 2003.

11. ABDELHAFEZ A.A., ABBAS M.H., ATTIA T. Environmental Monitoring of Heavy-Metals Status and Human Health Risk Assessment in the Soil of Sahl ElHessania Area, Egypt. Polish Journal of Environmental Studies. 24 (2), 459, 2015.

12. QIN H.-B., ZHU J.M., LIANG L., WANG M.S., SU H. The bioavailability of selenium and risk assessment for human selenium poisoning in high-Se areas, China. Environment International. 52 (66), 2013.

13. RAYMAN M. P. Food-chain selenium and human health: emphasis on intake. British Journal of Nutrition. 100 (2), 254, 2008.

14. WILLIAMS P. N., LOMBI E., SUN GX., SCHECKEL K., ZHU Y.G., FENG X., ZHU J., CAREY A.M., ADOMAKO E., LAWGALI Y. Selenium characterization in the global rice supply chain. Environmental Science \& Technology. 43 (15), 6024, 2009.

15. PREMARATHNA L., MCLAUGHLIN M.J., KIRBY J.K., HETTIARACHCHI G.M., STACEY S., CHITTLEBOROUGH D.J. Selenate-Enriched Urea Granules Are a Highly Effective Fertilizer for Selenium Biofortification of Paddy Rice Grain. Journal of Agricultural and Food Chemistry. 60 (23), 6037, 2012.

16. LI H.F., LOMBI E., STROUD J. L., MCGRATH S. P., ZHAO F.J. Selenium speciation in soil and rice: influence of water management and Se fertilization. Journal of Agricultural and Food Chemistry. 58 (22), 11837, 2010.

17. BROADLEY M.R., WHITE P.J., BRYSON R.J., MEACHAM M.C., BOWEN H.C., JOHNSON S.E., HAWKESFORD M.J., MCGRATH S.P., ZHAO F.J., BREWARD N. Biofortification of UK food crops with selenium. Proceedings of the Nutrition Society. 65 (02), 169, 2006.

18. BOROWSKA K., KOPER J. Dynamics of changes of selenium content in soil and red clover (Trifolium pratense L.) affected by long-term organic fertilization on the background of selected soil oxidoreductases. Polish Journal of Environmental Studies. 20 (6), 2011.

19. STROUD J., BROADLEY M., FOOT I., FAIRWEATHERTAIT S., HART D., HURST R., KNOTT P., MOWAT H., NORMAN K., SCOTT P. Soil factors affecting selenium concentration in wheat grain and the fate and speciation of Se fertilisers applied to soil. Plant and soil. 332 (1-2), 19, 2010.

20. WU L., GUO X., BA UELOS G. S. Selenium and sulfur accumulation and soil selenium dissipation in planting of four herbaceous plant species in soil contaminated with drainage sediment rich in both selenium and sulfur. International journal of phytoremediation. 5 (1), 25, 2003.

21. ALTANSUVD J., NAKAMARU Y. M., KASAJIMA S., ITO H., YOSHIDA H. Effect of long-term phosphorus fertilization on soil Se and transfer of soil Se to crops in northern Japan. Chemosphere. 107 (7), 2014.

22. DE TEMMERMAN L., WAEGENEERS N., THIRY C., DU LAING G., TACK F., RUTTENS A. Selenium content of Belgian cultivated soils and its uptake by field crops and vegetables. Science of the Total Environment. 468 (77), 2014. 
23. WU L., BANUELOS G., GUO X. Changes of soil and plant tissue selenium status in an upland grassland contaminated by selenium-rich agricultural drainage sediment after ten years transformed from a wetland habitat. Ecotoxicology and environmental safety. 47 (2), 201, 2000.

24. YU R., JI J., YUAN X., SONG Y., WANG C. Accumulation and translocation of heavy metals in the canola (Brassica napus L.) soil system in Yangtze River Delta, China. Plant and Soil. 353 (1-2), 33, 2012.

25. YUAN X., LI T., LI J., YE H., GE M. Origin and risk assessment of potentially harmful elements in river sediments of urban, suburban, and rural areas. Polish Journal of Environmental Studies. 22 (2), 599, 2013.

26. XIU ZHEN H., DONG MEI Z., HUANG D.Q., LONG C., ZHANG H.L., HUI W. Heavy metal transfer from soil to vegetable in southern Jiangsu Province, China. Pedosphere. 19 (3), 305, 2009.

27. MIZUTANI T., KANAYA K., OSAKA T. Map of Selenium Content in Soil in Japan. Journal of Health Science. 47 (4), 407, 2001

28. OTERO N., VITORIA L., SOLER A., CANALS A. Fertiliser characterisation: major, trace and rare earth elements. Applied geochemistry. 20 (8), 1473, 2005.

29. LIAO Q. L., LIU C., WU H. Y., JIN Y., HUA M., ZHU B. W., CHEN K., HUANG L. Association of soil cadmium contamination with ceramic industry: A case study in a Chinese town. Science of The Total Environment. 514 (26), 2015.

30. ZAYED A., LYTLE C. M., TERRY N. Accumulation and volatilization of different chemical species of selenium by plants. Planta. 206 (2), 284, 1998.

31. KAৃKLEWSKI K., NOWAK J., LIGOCKI M. Effects of selenium content in green parts of plants on the amount of ATP and ascorbate - glutathione cycle enzyme activity at various growth stages of wheat and oilseed rape. Journal of plant physiology. 165 (10), 1011, 2008.

32. HUANG Q., WANG Q., LUO Z., YU Y., JIANG R., LI H. Effects of root iron plaque on selenite and selenate dynamics in rhizosphere and uptake by rice (Oryza sativa). Plant and Soil. 388 (1-2), 255, 2014.

33. DUMONT E., VANHAECKE F., CORNELIS R. Selenium speciation from food source to metabolites: a critical review. Analytical and Bioanalytical Chemistry. 385 (7), 1304, 2006.

34. ZHANG C., QIU G., ANDERSON C. W. N., ZHANG H., MENG B., LIANG L., FENG X. Effect of atmospheric mercury deposition on selenium accumulation in rice (Oryza sativa L.) at a mercury mining region in Southwestern China. Environmental Science \& Technology. 2015.

35. ZHU Y.G., PILON SMITS E. A., ZHAO F.J., WILLIAMS P. N., MEHARGA.A. Selenium in higher plants: understanding mechanisms for biofortification and phytoremediation. Trends in plant science. 14 (8), 436, 2009.

36. GREEN I. D., TIBBETT M. Differential Uptake, Partitioning and Transfer of $\mathrm{Cd}$ and $\mathrm{Zn}$ in the Soil - Pea Plant - Aphid System. Environmental Science \& Technology. 42 (2), 450, 2007.
37. ZHANG L., SHI W., WANG X., ZHOU X. Genotypic differences in selenium accumulation in rice seedlings at early growth stage and analysis of dominant factors influencing selenium content in rice seeds. Journal of plant nutrition. 29 (9), 1601, 2006.

38. HOPPER J. L., PARKER D. R. Plant availability of selenite and selenate as influenced by the competing ions phosphate and sulfate. Plant and Soil. 210 (2), 199, 1999.

39. KHATTAK R. A., PAGE A., PARKER D., BAKHTAR D. Accumulation and interactions of arsenic, selenium, molybdenum and phosphorus in alfalfa. Journal of environmental quality. 20 (1), 165, 1991.

40. WHITE P., BOWEN H., PARMAGURU P., FRITZ M., SPRACKLEN W., SPIBY R., MEACHAM M., MEAD A., HARRIMAN M., TRUEMAN L. Interactions between selenium and sulphur nutrition in Arabidopsis thaliana. Journal of Experimental Botany. 55 (404), 1927, 2004.

41. MA J. F., YAMAJI N., MITANI N., XU X.Y., SU Y.H., MCGRATH S. P., ZHAO F.J. Transporters of arsenite in rice and their role in arsenic accumulation in rice grain. Proceedings of the National Academy of Sciences. 105 (29), 9931, 2008.

42. MOUNICOU S., SHAH M., MEIJA J., CARUSO J. A., VONDERHEIDE A. P., SHANN J. Localization and speciation of selenium and mercury in Brassica juncea implications for Se-Hg antagonism. Journal of Analytical Atomic Spectrometry. 21 (4), 404, 2006.

43. LI Y.F., ZHAO J., LI Y., LI H., ZHANG J., LI B., GAO Y., CHEN C., LUO M., HUANG R. The concentration of selenium matters: a field study on mercury accumulation in rice by selenite treatment in qingzhen, Guizhou, China. Plant and Soil. 391 (1-2), 195, 2015.

44. WANG X., TAM N. F.Y., FU S., AMETKHAN A., OUYANG Y., YE Z. Selenium addition alters mercury uptake, bioavailability in the rhizosphere and root anatomy of rice (Oryza sativa). Annals of botany. mcu117, 2014.

45. HU Y., NORTON G. J., DUAN G., HUANG Y., LIU Y. Effect of selenium fertilization on the accumulation of cadmium and lead in rice plants. Plant and Soil. 384 (1-2), 131, 2014.

46. TERRY N., ZAYED A., DE SOUZA M., TARUN A. Selenium in higher plants. Annual review of plant biology. 51 (1), 401, 2000.

47. SORS T., ELLIS D., SALT D. Selenium uptake, translocation, assimilation and metabolic fate in plants. Photosynthesis research. 86 (3), 373, 2005.

48. HAWKESFORD M. J., ZHAO F. J. Strategies for increasing the selenium content of wheat. Journal of Cereal Science. 46 (3), 282, 2007.

49. ALIFAR N., RAHMAN Z., ISHAK C., AWANG Y., KHAYYAMBASHI B. The effect of different rates of selenium on grain Se concentration and yield of MR219 rice (Oryza sativa L.). Humanities, Science and Engineering (CHUSER), 2012 IEEE Colloquium; 126, Malaysia, 2012. 
